\title{
Effect of routine Hepatitis $B$ vaccination program in Southeast of Turkey? Comparing of the results of HBV DNA in terms of age groups for the years 2002 and 2012
}

\author{
TUNCER OZEKINCI, SELAHATTIN ATMACA, TUBA DAL \\ Department of Medical Microbiology, Dicle University, School of Medicine, Turkey
}

\begin{abstract}
Diyarbakir is the largest residential area in the Southeastern Anatolia of Turkey. Routine HBV vaccination has begun to be implemented by the Ministry of Health in Turkey in 1998. The purposes of this study were to detect the levels of HBV DNA in patients with HBV in 2012, and to compare the results of the year 2002 according to age groups. HBV DNA results of patients were divided in to seven age groups (0-14, 15-20, 21-30, 31-40, 41-50, 51-60, and > 61 years) and for comparison of HBV DNA levels of 2002 and 2012, HBV DNA values in pg/ml of year 2002 were translated into IU/ml and HBV DNA levels were grouped as $<5 \mathrm{pg} / \mathrm{ml}<2.43 \times 10^{5} \mathrm{IU} / \mathrm{ml}, 5-100 \mathrm{pg} / \mathrm{ml} 2.43 \times 10^{5}-4.86 \times 106 \mathrm{IU} /$ $\mathrm{ml}, 101-2000 \mathrm{pg} / \mathrm{ml} 4.87 \times 10^{6}-9.72 \times 10^{7} \mathrm{IU} / \mathrm{ml},>2000 \mathrm{pg} / \mathrm{ml}>9.72 \times 10^{7} \mathrm{IU} / \mathrm{ml} 2-3$. A statistically significant decrease was seen in the number of individuals in 0-14 age group in 2012 compared with 2002. In 2002 the rate of individuals in 0-14 age group was $18.8 \%$ whereas $4.8 \%$ in 2012 . Our study was suggested that that routine $H B V$ vaccination program, contributed to the reduced risk of $H B V$ infection in our region.
\end{abstract}

Key words: hepatitis B, vaccination, Turkey.

(Centr Eur J Immunol 2014; 39 (1): 122-123)

Diyarbakır is the largest residential area in the Southeastern Anatolia of Turkey. Rural-urban migration is common in Diyarbakir. Increased population, lack of infrastructure, high young population, poor personal hygiene may lead to an increase in hepatitis B prevalence. The rate of hepatitis B virus (HBV) carriers ranges from $4 \%$ to $12 \%$ in Turkey. In 2004 , HBsAg seroprevalence was found to be $8.2 \%$ in rural areas, and $6.2 \%$ in urban areas. In our region, HBsAg seroprevalence was higher than in other regions of Turkey [1].

Routine HBV vaccination began to be implemented by the Ministry of Health in Turkey in 1998.

The purpose of this study was to detect the levels of HBV DNA in patients with HBV in 2012, and to compare the results of 2002 according to age groups.

A total of 1225 patients with hepatitis B confirmed serologically in 2002 and 1300 patients with hepatitis B confirmed serologically in 2012 were included in this study. HBV DNA results of patients were divided into seven age groups (0-14, 15-20, 21-30, 31-40, 41-50, 51-60, and > 61 years). Hepatitis B virus DNA levels of the patients in
2012 were detected by real-time PCR (Ampli-Prep/COBAS COBAS TaqMan HBV Test v.2, Roche Molecular Systems, USA) method. Hepatitis B virus DNA levels of patients of 2002 were investigated by Digene Hybrid Capture method (Digene Corporation, Gaithersburg, Md20878, USA). In this study, for comparison of HBV DNA levels of 2002 and 2012, HBV DNA values in $\mathrm{pg} / \mathrm{ml}$ of 2002 were translated into $\mathrm{IU} / \mathrm{ml}$ and HBV DNA levels were grouped as $<5 \mathrm{pg} / \mathrm{ml}<2.43 \times 10^{5} \mathrm{IU} / \mathrm{ml}, 5-100 \mathrm{pg} / \mathrm{ml} 2.43$ $\times 10^{5}-4.86 \times 10^{6} \mathrm{IU} / \mathrm{ml}, 101-2000 \mathrm{pg} / \mathrm{ml} 4.87 \times 10^{6}-9.72$ $\times 10^{7} \mathrm{IU} / \mathrm{ml}$, and $>2000 \mathrm{pg} / \mathrm{ml}>9.72 \times 10^{7} \mathrm{IU} / \mathrm{ml}[2,3]$.

Distribution of the HBV DNA results according to different age groups obtained from both years was shown in Table 1. A statistically significant decrease was seen in the number of individuals in 0-14 age group in 2012 compared with 2002. In 2002, the rate of individuals in 0-14 age group was $18.8 \%$, whereas in 2012 it was $4.8 \%$.

Our study suggested that the routine HBV vaccination program contributed to the reduced risk of HBV infection in our region.

Correspondence: Tuba Dal, Dicle University, Shool of Medicine, Department of Medical Microbiology, Diyarbakir, Turkey, e-mail: tuba-dal@yahoo.com 
Table 1. Distribution of the HBV DNA results according to different age groups

\begin{tabular}{|c|c|c|c|c|c|}
\hline Age groups & $\begin{array}{l}\text { Number } \\
\text { of patients }\end{array}$ & $\begin{array}{c}<2.43 \times 10^{5} \mathrm{IU} / \mathrm{ml} \\
(<5 \mathrm{pg} / \mathrm{ml})\end{array}$ & $\begin{array}{c}2.43 \times 10^{5}-4.86 \times 10^{6} \mathrm{IU} / \mathrm{ml} \\
(5-100 \mathrm{pg} / \mathrm{ml})\end{array}$ & $\begin{array}{c}4.87 \times 10^{6}-9.72 \times 10^{7} \mathrm{IU} / \mathrm{ml} \\
(101-2000 \mathrm{pg} / \mathrm{ml})\end{array}$ & $\begin{array}{c}>9.72 \times 10^{7} \mathrm{IU} / \mathrm{ml} \\
(>2000 \mathrm{pg} / \mathrm{ml})\end{array}$ \\
\hline $0-14^{*}$ & $231(18.86 \%)$ & $126(54.55 \%)$ & $6(2.60 \%)$ & $20(8.65 \%)$ & $79(34.20 \%)$ \\
\hline $0-14 * *$ & $63(4.80 \%)$ & $40(63.50 \%)$ & $5(7.90 \%)$ & $3(4.80 \%)$ & $15(23.80 \%)$ \\
\hline $15-20^{*}$ & $129(10.53 \%)$ & $80(62.02 \%)$ & $11(8.53 \%)$ & $7(5.43 \%)$ & $31(24.03 \%)$ \\
\hline $15-20 * *$ & $148(11.40 \%)$ & $106(71.60 \%)$ & $10(6.80)$ & $7(4.70)$ & $25(16.90)$ \\
\hline $21-30^{*}$ & $378(30.86)$ & 267 (70.63) & $35(9.26)$ & $14(3.70)$ & $62(16.40)$ \\
\hline $21-30 * *$ & $371(28.5)$ & $328(88.40)$ & $8(2.20)$ & $10(2.70)$ & $25(6.70)$ \\
\hline $31-40^{*}$ & $236(19.27)$ & $195(82.63)$ & $14(5.93)$ & $15(6.36)$ & $12(5.08)$ \\
\hline $31-40^{* *}$ & $331(25.50)$ & $310(93.70)$ & $5(1.50)$ & $10(3.0)$ & $6(1.80)$ \\
\hline $41-50 *$ & $146(11.92)$ & $116(79.45)$ & $14(9.59)$ & $10(6.85)$ & $6(4.11)$ \\
\hline $41-50$ ** & $232(17.90)$ & 215 (92.70) & $6(2.60)$ & $5(2.10)$ & $6(2.60)$ \\
\hline $51-60^{*}$ & $56(4.57)$ & $48(85.71)$ & $5(8.93)$ & $1(1.79)$ & $2(3.57)$ \\
\hline $51-60^{* *}$ & $105(8.10)$ & $104(99.00)$ & - & - & $1(1.0)$ \\
\hline$>61^{*}$ & $49(4.00)$ & $40(81.64)$ & $1(2.04)$ & $5(10.20)$ & $3(6.12)$ \\
\hline$>61 * *$ & $50(3.80)$ & $50(100.00)$ & - & - & - \\
\hline Total* & $1225(100)$ & $872(71.18)$ & $86(7.02)$ & $72(5.88)$ & $195(15.92)$ \\
\hline Total** & $1300(100)$ & $1153(88.70)$ & $34(2.60)$ & $35(2.70)$ & $78(6.00)$ \\
\hline
\end{tabular}

*data for the year 2002

**data for the year 2010

Authors declare no conflict of interest.

\section{References}

1. Mehmet D, Meliksah E, Serif Y, et al. (2005): Prevalence of hepatitis B infection in southeastern region of Turkey: comparison of risk factors for HBV Infection in rural and urban areas. Jpn J Infect Dis 58: 15-19.

2. Ozekinci T, Ozerdem N, Atmaca S, Elçi S (2003): Distribution of HBV DNA according to age group in the Diyarbakır region (southeast Turkey). J Infect 46: 145-146.

3. Pawlotsky JM. Hepatitis B virus (HBV) DNA assays (methods and practical use) and viral kinetics. J Hepatol 2003; 39 Suppl 1: 31-35. 